\title{
PENGARUH MOTIVASI KERJA, LINGKUNGAN KERJA DAN PENEMPATAN KERJA TERHADAP SEMANGAT KERJA KARYAWAN TETAP DI KOPERASI WARGA SEMEN GRESIK (KWSG)
}

\author{
Devi Oktavia Puspita Sari \\ Program Studi Manajemen Fakultas Ekonomi dan Bisnis \\ Universitas Muhammadiyah Gresik
}

\begin{abstract}
The purpose of this study to determine the effect of work motivation, work environment and job placement on the morale of permanent employee of Semen Gresik Cooperative. The sample uses the proportionate stratified random sampling method which is a sampling technique when an organization has employees from the background of stratified positions totaling 106 people. Data analysis techniques use multiple linear regression. The result of multiple linear regression analysis proves that the work motivation, work environment and job placement have a significant effect on the morale of permanent employee of Semen Gresik Cooperative.
\end{abstract}

Keywords: Work Motivation, Work Environment, Job Placement and Spirit Work

\section{PENDAHULUAN}

Peran sumber daya manusia dalam suatu organisasi sangatlah penting karena sebagai penggerak utama dari seluruh kegiatan atau aktivitas dalam mencapai suatu tujuan sekaligus untuk memperoleh keuntungan maupun untuk mempertahankan eksistensi organisasi dimulai dari usaha mengelola sumber daya manusia, khususnya meningkatkan efektifitas dan efisiensi kerja secara maksimal.

Perusahaan adalah wujud kolektifitas dari modal kerja, keterampilan, kewirausahaan, kemampuan managerial dan juga yang terutama adalah sumber daya manusia sebagai aspek penggerak utama. Tanpa adanya SDM dalam perusahaan , maka seluruh perencanaan perusahaan, sumber modal kerja, dan lain sebagainya hanyalah menjadi sesuatu yang tidak berarti karena tanpa operator yang menggerakannya. Koperasi Warga Semen Gresik
(KWSG) adalah koperasi yang memiliki konsep koperasi negara berkembang dimana terdapat ciri khusus adanya campur tangan pemerintah. Koperasi ini berharap pada semangat kerja karyawan yang tinggi, agar perusahaan dapat bertahan dalam persaingan global.

Semangat kerja karyawan dipengaruhi oleh beberapa faktor, antara lain: kepemimpinan, motivasi, komunikasi, hubungan manusiawi, penempatan kerja, kompensasi, dan lingkungan kerja (Nitisemito, 2015;112). Pada penelitian ini akan dibahas mengenai motivasi kerja, lingkungan kerja, dan penempatan kerja terhadap semangat kerja karyawan.

Motivasi adalah keinginan yang timbul dari dalam diri seseorang atau individu karena terinspirasi, tersemangati dan terdorong untuk melakukan aktivitas dengan keikhlasan, senang hati dan sungguh- 
sungguh sehingga hasil dari aktivitas yang dia lakukan mendapat hasil yang baik dan berkualitas (Afandi, 2016;12). Salah satu indikator motivasi kerja menurut Abraham Maslow dalam Hasibuan $(2016 ; 154)$ adalah kebutuhan fisiologi yang berupa pemberian bonus dan sebagainya.

Lingkungan kerja dipengaruhi oleh beberapa faktor menurut Nitisemito (2015;184), antara lain: pewarnaan, kebersihan, pertukaran udara, penerangan, musik, keamanan, dan kebisingan. Dalam perusahaan sangat diperlukan juga suasana kerja yang menyenangkan dalam artian memiliki hubungan baik antar sesama karyawan serta antara karyawan dengan atasan, maka akan menimbulkan semangat kerja karyawan. Semangat kerja karyawan juga dapat didukung dengan penempatan kerja yang baik di lihat dari kesesuaian dengan minat karyawan, kesesuaian dengan latar belakang pendidikan karyawan, dan kesesuaian dengan pengalaman kerja karyawan (Wahyudi dalam Yuniarsih, 2011;117)

Penempatan kerja karyawan adalah tindak lanjut dari seleksi, menempatkan calon karyawan yang diterima pada jabatan/ pekerjaan yang dibutuhkan dan sekaligus mendelegasikan authority kepada calon karyawan (Hasibuan, 2016;32).

Permasalahan yang ada dilapangan menunjukkan masih terdapat faktor yang kurang memuaskan karyawan umumnya yang berkaitan dengan motivasi, lingkungan kerja, maupun penempatan. Dalam motivasi misalnya permasalahan timbul karena perlu diperhatikan juga tentang kebutuhan keselamatan dan keamanan, kebutuhan sosial, kebutuhan penghargaan, dan juga aktualisasi diri untuk memotivasi agar karyawan semangat bekerja. Sementara dalam lingkungan kerja adalah pencahayaan yang kurang terang pada bagian Kepegawaian. Untuk penempatan kerja permasalahan timbul karena adanya ketidak tepatan dalam penempatan kerja yang sesuai spesifikasi jabatan dengan pendidikan karyawan.

Judul dalam penelitian ini adalah "Pengaruh Motivasi Kerja, Lingkungan Kerja dan Penempatan Kerja Terhadap Semangat Kerja Karyawan Tetap di Koperasi Warga Semen Gresik (KWSG)”.

\section{TINJAUAN PUSTAKA}

Penelitian yang dilakukan oleh Kholiq Kurniawan (2016), dengan judul "Pengaruh Faktor-Faktor Lingkungan Kerja Fisik Terhadap Semangat Kerja Karyawan Construction Division di PT. Catur Elang Perkasa Surabaya". Alat analisis yang digunakan dalam penelitian ini dengan analisis regresi linear berganda. Hasil penelitian ini menyimpulkan bahwa hasil uji hipotesis secara simultan melalui uji $\mathrm{F}$ menyatakan bahwa variabel Udara, Penerangan, Suara bising, Tata Warna, Ruang Gerak dan Keamanan secara simultan memiliki pengaruh terhadap Semangat Kerja Karyawan Construction Division PT. Catur Elang Perkasa.

\section{Motivasi Kerja}

Menurut Sutrisno $(2014 ; 109)$ Motivasi adalah suatu faktor yang mendorong seseorang untuk melakukan suatu aktivitas tertentu, oleh karena itu motivasi sering kali diartikan pula sebagai faktor pendorong perilaku seseorang. Setiap aktivitas yang dilakukan oleh seorang pasti memiliki suatu faktor yang mendorong aktivitas tersebut. 
Menurut Hasibuan (2016;146) ada beberapa tujuan yang diperoleh dari pemberian motivasi, yaitu : meningkatkan moral dan kepuasan kerja karyawan, meningkatkan produktivitas kerja karyawan, mempertahankan kestabilan karyawan dalam perusahaan, meningkatkan kedisiplinan pegawai/ karyawan, mengefektifkan pengadaan karyawan, menciptakan suasana dan hubungan kerja yang baik. Motivasi sebagai psikologi dalam diri seseorang dipengaruhi oleh beberapa faktor, baik yang bersifat internal maupun eksternal oleh Sutrisno ( 2014;116).

Faktor internal (berasal dari dalam diri karyawan), yang mempengaruhi pemberian motivasi pada diri seseorang, antara lain: keinginan untuk dapat hidup, keinginan untuk dapat memiliki, keinginan untuk memperoleh penghargaan, keinginan untuk memperoleh pengakuan, dan keinginan untuk berkuasa.

\section{Lingkungan Kerja}

Lingkungan kerja adalah segala sesuatu yang ada disekitar para pekerja dan yang dapat mempengaruhi dirinya dalam menjalankan tugas-tugas yang dibebankan (Nitisemito, 2015;184). Menurut Sedarmayanti $\quad(2012 ; 21)$ menyatakan bahwa secara garis besar, jenis lingkungan kerja terbagi menjadi 2 yakni : Lingkungan kerja fisik dan Lingkungan kerja non fisik.

Beberapa faktor yang mempengaruhi lingkungan kerja menurut Nitisemito $(2015 ; 184)$, faktor-faktor tersebut antara lain sebagai berikut: pewarnaan, kebersihan, pertukaran udara, penerangan, musik, keamanan, dan kebisingan.

\section{Penempatan Kerja}

Hasibuan (2016;32) menyatakan bahwa penempatan kerja karyawan adalah tindak lanjut dari seleksi, menempatkan calon karyawan yang diterima pada jabatan/ pekerjaan yang dibutuhkannya dan sekaligus mendelegasikan authority kepada calon karyawan tersebut. Penempatan pegawai dapat dilakukan dalam beberapa jenis penempatan (Priansa, 2016;126).

Penempatan pegawai terdiri dari dua cara, yaitu : pegawai baru dari luar organisasi, dan Penugasan di tempat baru bagi pegawai lama yang yang disebut inplacemen. terdapat tiga konteks yang penting dari penempatan, yaitu promosi, transfer, dan demosi. Priansa $(2016 ; 129)$ menyatakan terdapat sejumlah faktorfaktor yang mempengaruhi penempatan pegawai dalam organisasi, yaitu : faktor prestasi akademis, faktor pengalaman, faktor kesehatan fisik dan mental, faktor status perkawinan, dan faktor usia.

\section{Semangat Kerja}

Nitisemito $(2015 ; 160)$ menyatakan bahwa semangat kerja adalah melakukan pekerjaan dengan lebih giat sehingga dengan demikian pekerjaan dapat selesai lebih cepat dan lebih baik. Lebih lanjut di artikan semangat kerja sebagai sesuatu yan positif dan sesuatu baik, sehingga mampu memberikan sumbangan terhadap pekerjaan dalam arti lebih cepat dan baik.

Dengan semangat kerja pekerjaan akan lebih cepat untuk di selesaikan, absensi akan dapat diperkecil, kemungkinan perpindahan karyawan dapat diperkecil seminimal mungkin. Oleh karena itu sudah selayaknya apabila setiap perusahaan selalu berusaha supaya para karyawan 
mempunyai moral kerja yang tinggi, karena dengan moral kerja yang tinggi diharapkan semangat kerja akan meningkat.

Terdapat Tujuh faktor yang mempengaruhi semangat kerja, Nitisemito $(2015 ; 112)$. Tujuh faktor tersebut yakni di jabarkan di bawah ini: kepemimpinan, motivasi, komunikasi, penempatan, lingkungan kerja, hubungan manusiawi, kompensasi, dan lingkungan kerja.

\section{Hubungan Lingkungan Kerja} Dengan Semangat Kerja Karyawan Menurut Moekijat $(2011 ; 15)$ lingkungan kerja yang baik dan mendukung dapat meningkatkan semangat kerja karyawan, karena dengan adanya lingkungan yang baik akan mendorong karyawan untuk melaksanakan tugasnya dengan baik dan tidak malas, sehingga memacu semangat karyawan untuk melaksanakan pekerjaannya. Hal ini dapat disimpulkan bahwa hubungan lingkungan kerja dengan semangat kerja bersifat positif.

\section{Hubungan Penempatan Kerja Dengan Semangat Kerja Karyawan} Menurut Nitisemito $\quad(2015 ; 174)$ ketepatan dalam menempatkan posisi para karyawan akan menyebabkan semangat kerja karyawan akan maksimal. Dengan demikian dapat cepat diketahui tempat mana yang paling tepat bagi masing- masing karyawan. Hal ini dapat disimpulkan bahwa hubungan penempatan kerja dengan semangat kerja bersifat positif.

\section{Hipotesis}

Berdasarkan latar belakang dan permasalahan yang ada diarahkan untuk dugaan sementara, yaitu:

H1 : diduga ada pengaruh motivasi kerja terhadap semangat kerja karyawan tetap di Koperasi Warga Semen Gresik (KWSG).

$\mathrm{H} 2$ : diduga ada pengaruh lingkungan kerja terhadap semangat kerja karyawan tetap di Koperasi Warga Semen Gresik (KWSG).

$\mathrm{H} 3$ : diduga ada pengaruh penempatan kerja terhadap semangat kerja karyawan tetap di Koperasi Warga Semen Gresik (KWSG).

\section{METODE PENELITIAN}

Penelitian ini menggunakan pendekatan kuantitatif. Penelitian ini dilakukan pada Koperasi Warga Semen Gresik (KWSG). Adapun populasi dalam penelitian ini adalah karyawan tetap KWSG dengan jumlah 144 karyawan. besarnya sampel pada penelitian ini adalah 106.

Pengambilan sampel dalam penelitian ini menggunakan teknik probability sampling dengan jenis propotionate stratified random sampling yang merupakan teknik pengambilan sampel bila suatu organisasi yang mempunyai karyawan dari latar belakang jabatan yang berstrata (Sugiyono 2015;82).

Pada penelitian ini, jenis data yang dipakai oleh peneliti adalah Data Primer. Data primer adalah data yang diperoleh secara langsung dikumpulkan oleh peneliti dari lapangan atau obyek penelitian sesuai dengan variabel yang diteliti kemudian diolah. Teknik pengambilan data dalam penelitian ini dengan menggunakan kuesioner. Kuesioner merupakan teknik pengumpulan data yang dilakukan dengan cara memberi seperangkat pertanyaan atau pertanyaan tertulis kepada responden untuk dijawab Sugiyono $(2015 ; 142)$.

Sesuai dengan hipotesis yang diajukan, dengan memahami fenomena yang diteliti maka variabel yang ada didalam penelitian ini adalah 
sebagai berikut : Variabel bebas yang digunakan dalam penelitian ini : Motivasi Kerja (X1), Lingkungan Kerja (X2), dan Penempatan Kerja (X3), sedangkan variabel terikatnya adalah Semangat Kerja Karyawan (Y).

Pada penelitian ini teknik analisis data menggunakan pengujian hipotesis dengan menggunakan uji statistik, yaitu melalui analisis regresi. Analisis regresi linier berganda dimaksut untuk menganalisis pengaruh dari variabel Motivasi Kerja $\left(\mathrm{X}_{1}\right)$, Lingkungan Kerja $\left(\mathrm{X}_{2}\right)$ dan Penempatan Kerja $\left(\mathrm{X}_{3}\right)$, terhadap Semangat Kerja Karyawan (Y) dengan persamaan berikut :

$$
\mathrm{Y}=\mathrm{a}+\mathrm{b}_{1} \mathrm{x}_{1}+\mathrm{b}_{2} \mathrm{x}_{2}+\mathrm{b}_{3} \mathrm{x}_{3}+\mathrm{e}
$$

\section{HASIL PENELITIAN Sejarah KWSG}

Koperasi Warga Semen Gresik (KWSG) adalah koperasi milik PT. Semen Gresik (Persero) Tbk. Perusahaan ini berdiri sejak tanggal 29 Januari 1963 dengan nama Koperasi Serba Usaha Karyawan Perusahaan Negara Semen Gresik, dalam memulai bisnisnya koperasi menjalani usahanya di bidang perdagangan pokok sayur mayur untuk memenuhi kebutuhan karyawan PT. Semen Gresik.

Koperasi Warga Semen Gresik (KWSG) merupakan koperasi di Indonesia yang mampu menembus koperasi kelas dunia menurut International Co-operative Aliance (ICA). ICA merupakan organisasi non pemerintah yang memiliki serikat koperasi di seluruh dunia, perusahaan yang berdiri sejak tahun 1895 tersebut memiliki 269 federasi koperasi di 94 negara negara di Afrika, Asia, Pasifik, dan Amerika yang sudah di akui dunia dengan eksistensinya sebagai
Lembaga Koperasi Internasional. Hingga 2013 ICA memiliki anggota sebanyak 1 Milliar yang berada di seluruh dunia. Koperasi Warga Semen Gresik (KWSG) adalah koperasi yang memiliki konsep koperasi negara berkembang dimana terdapat, ciri khusus adanya campur tangan pemerintah. Koperasi Warga Semen Gresik (KWSG) berada di bawah naungan salah satu perusahaan semen milik BUMN. Didalamnya pemerintah juga berperan aktif untuk memberikan akses informasi dan fasilitas dalam rangka peningkatan kapasitas.

Koperasi Warga Semen Gresik (KWSG) adalah koperasi yang menganut aliran Persemakmuran. Di dalam menjalankan kegiatannya, pemerintah melakukan pengawasan, perijinan, serta pembinaan dalam beberapa hal. Koperasi Warga Semen Gesik (KWSG) juga melakukan kerjasama dengan lembaga-lembaga pemerintah seperti kepada Bank Mandiri dalam hal permodalan.

\section{Visi dan Misi}

\section{VISI}

"Mendominasi bisnis perdagangan bahan bangunan di Asia Tenggara

\section{MISI}

1. Membangun kesejahteraan anggota, pegawai dan pemangku kepentingan lainnya sesuai cita-cita luhur koperasi.

2. Menciptakan insan KWSG yang profesional, produktif dan kredibel.

3. Berorientasi pada perbaikan berkelanjutandengan "Good Corporate Governace". Mengadopsi perkembangan teknologi informasi dan sistem manajemen modern.

\section{Analisis Data}

Langkah-langkah menganalisa data dalam penelitian ini adalah sebagai berikut : 
1. Melakukan perhitungan untuk setiap variabel yang nantinya akan di analisis lebih lanjut dalam program SPSS, seperti tertera pada lampiran penelitian ini.

2. Melakukan pengujian instrumen yang terdiri dari uji validitas dan uji reliabilitas..

3. Melakukan pengujian asumsi klasik yang terdiri dari uji multikolineritas, uji hesteroskedastisitas, dan uji normalitas,

4. Melakukan analisis regresi linier berganda.

5. Melakukan pengujian koefisien determinasi $\mathrm{R}^{2}$.

6. Melakukan pengujian hipotesis secara parsial ( uji t).

\section{Interpretasi Hasil}

Penelitian ini membuktikan hipotesis regresi linier secara parsial dengan menggunakan uji $\mathrm{t}$ ditunjukkan untuk mengetahui pengaruh masing-masing variabel independen yang terdiri dari Motivasi Kerja $\left(\mathrm{X}_{1}\right)$, Lingkungan Kerja $\left(X_{2}\right)$ dan Penempatan Kerja $\left(X_{3}\right)$ secara parsial terhadap variabel dependen yaitu Semangat Kerja Karyawan Tetap Koperasi Warga Semen Gresik (Y).

\section{Motivasi Kerja (X1) terhadap Semangat Kerja Karyawan (Y)}

Hasil penelitian terhadap variabel motivasi kerja $\left(\mathrm{X}_{1}\right)$ terhadap semangat kerja karyawan diperoleh $\mathrm{t}$ hitung sebesar 3,362 > t tabel sebesar 1,983 dengan taraf signifikansi 5\%, maka terbukti bahwa motivasi kerja $\left(\mathrm{X}_{1}\right)$ berpengaruh signifikan terhadap semangat kerja karyawan tetap Koperasi Warga Semen Gresik.

Hal ini disebabkan oleh sistem motivasi yang diberikan oleh Koperasi Warga Semen Gresik terhadap karyawan sudah sesuai dengan keinginan para karyawannya terlihat dari data motivasi kerja pada tabel 1.1. Pada tabel tersebut terdapat pemberian motivasi berbentuk insentif kerja mencapai dua kali gaji, THR, dan bonus hingga empat kali gaji sebagai bentuk dukungan perusahaan terhadap karyawan yang ingin mencapai hasil kerja yang optimal.

Dilihat dari hasil tanggapan penilaian responden tentang motivasi kerja pada tabel 4.6, karyawan lebih dominan menjawab setuju dengan segala sesuatu yang diberikan perusahaan sebagai bentuk motivasi terhadap karyawan, di dukung dengan penelitian terdahulu yaitu Wisnu (2016) yang menyatakan bahwa motivasi kerja berpengaruh secara signifikan terhadap semangat kerja karyawan.

\section{Lingkungan Kerja (X2) terhadap Semangat Kerja Karyawan (Y)}

Hasil penelitian terhadap variabel lingkungan kerja $\left(\mathrm{X}_{2}\right)$ terhadap semangat kerja karyawan diperoleh $\mathrm{t}$ hitung sebesar 3,203 > t tabel sebesar 1,983 dengan taraf signifikansi 5\%, maka terbukti bahwa lingkungan kerja $\left(\mathrm{X}_{2}\right)$ berpengaruh signifikan terhadap semangat kerja karyawan tetap Koperasi Warga Semen Gresik.

Hal ini di sebabkan oleh fasilitas dan hubungan antar karyawan di Koperasi Warga Semen Gresik sudah sesuai dengan keinginan para karyawannya, sehingga karyawan akan nyaman dengan lingkungan kerja di perusahaan dan karyawan dapat menjalankan tugas dengan semangat, dan dilihat dari hasil tanggapan penilaian responden tentang lingkungan kerja pada tabel 4.7, karyawan lebih dominan menjawab setuju dengan lingkungan kerja yang ada disekitar perusahaan. Hal ini didukung oleh penelitian terdahulu 
oleh Kurniawan (2016) yang menyatakan bahwa lingkungan kerja berpengaruh signifikan terhadap semangat kerja karyawan.

\section{Penempatan Kerja (X3) Terhadap Semangat Kerja Karyawan (Y)}

Hasil penelitian terhadap variabel penempatan kerja $\left(\mathrm{X}_{3}\right)$ terhadap semangat kerja karyawan diperoleh $\mathrm{t}$ hitung sebesar 4,832 > t tabel sebesar 1,983 dengan taraf signifikansi 5\%, maka terbukti bahwa penempatan kerja $\left(\mathrm{X}_{3}\right)$ berpengaruh signifikan terhadap semangat kerja karyawan tetap Koperasi Warga Semen Gresik.

Hal ini disebabkan oleh kesesuaian dalam menempatkan karyawan dengan menentukan kompetensi karyawan, seperti: kesesuaian dengan minat karyawan, kesesuaian dengan latar belakang pendidikan karyawan, dan kesesuain dengan pengalaman kerja karyawan. Minat, pendidikan, dan pengalaman kerja yang tepat seorang karyawan pada umumnya akan mampu menyelesaikan tugas-tugas yang diembankan kepadanya secara baik dan benar.

Dilihat dari hasil tanggapan penilaian responden tentang penempatan kerja pada tabel 4.8, karyawan sebagian besar menjawab setuju, didukung oleh peneliti terdahulu yaitu Yusani (2016) yang menyatakan bahwa penempatan kerja berpengaruh signifikan terhadap semangat kerja karyawan.

\section{SIMPULAN}

DAN

\section{REKOMENDASI}

\section{Simpulan}

Berdasarkan hasil pengolahan data dalam penelitian ini dapat ditarik kesimpulan sebagai berikut:
1. Motivasi kerja berpengaruh signifikan secara persial terhadap Semangat Kerja Karyawan Tetap Koperasi Warga Semen Gresik.

2. Lingkungan kerja berpengaruh signifikan secara persial terhadap Semangat Kerja Karyawan Tetap Koperasi Warga Semen Gresik.

3. Penempatan kerja berpengaruh signifikan secara persial terhadap Semangat Kerja Karyawan Tetap Koperasi Warga Semen Gresik.

\section{Rekomendasi}

1. Bagi Perusahaan

Perusahaan sebaiknya sebelum menempatkan karyawan pada jabatan yang dibutuhkan oleh perusahaan, hendaknya terlebih dahulu mempertimbangkan dengan teliti serta menyesuaikan dalam menentukan kompetensi karyawan, seperti: kesesuaian dengan minat karyawan, kesesuaian dengan latar belakang pendidikan karyawan, dan kesesuain dengan pengalaman kerja karyawan. Agar tidak menghambat tujuan yang telah di tetapkan oleh perusahaan.

2. Bagi Peneliti Selanjutnya

Bagi peneliti selanjutnya hasil dari penelitian ini dapat digunakan sebagai referensi bagi peneliti selanjutnya dengan cara memperbanyak jumlah-jumlah variabel-variabelnya dan menggunakan teknik analisis yang berbeda-beda.

DAFTAR PUSTAKA

Afandi, Pandi, (2016), Concept And Indicator Human Resourcer Management For Management Reserth, Cetakan Ke-1, CV Budi Utama Yogyakarta. 
Fauzi, Husni, (2013), Pengaruh Stres

Kerja dan Konflik Kerja terhadap Semangat Kerja

Karyawan di PT. Karya Mandiri Environment Universitas

Pasundan, Bandung.

Ghozali, Imam, (2016), Aplikasi Analis Multivariate Dengan Program IBM SPSS 21, Edisi 2, Universitas Diponegoro, Semarang.

Handoko, T. Hani, (2012), Manajemen Personalia \& Sumber Daya Manusia Edisi kedua, Cetakan Ke-19, Penerbit BPFE, Yogyakarta.

Hasibuan, Malayu. (2016), Manajemen Sumber Daya Manusia. Bumi Aksara, Jakarta.

Kurniawan, Kholiq (2016), Pengaruh Faktor-Faktor Lingkungan Kerja Fisik Terhadap Semangat Kerja Karyawan Construction Division di PT. Catur Elang Perkasa Surabaya, Universitas Muhammadiyah Gresik.

Kusuma, Y.W, (2016), Pengaruh Motivasi kerja dan Insentif terhadap Semangat Kerja KAryawan CV. F.A Management, Jurnal Ilmu dan Riset Manajemen Vol. 5 No. 2, Sekolah Tinggi Ilmu Ekonomi Indonesia (STESIA) Surabaya.

\footnotetext{
Mangkunegara, A. P, (2011), Manajemen Sumber Daya Manusia Perusahaan, Remaja Rosdakarya, Bandung.
}

Mangkunegara, A. P, (2013), Manajemen Sumber Daya Manusia Perusahaan, Remaja Rosdakarya, Bandung.

Moekijat, (2011), Manajemen Sumber Daya Manusia, Mandar Maju, Bandung.

MurdiartaUtama, Wayan, Ardana, I Komang, dan Muljiati, Wayan. (2011), Manajemen Sumber Daya Manusia, Universitas Udayan, Denpasar.

Nitisemito, Alex. S, (2015), Manajemen Personalia, Ghalia Indonesia, Jakarta.

Priansa, Donni. (2016), Perencanaan \& Pengembangan SDM, Alfabeta, Bandung.

Rivai, Veithzal dan Ella Djauhari Sagala. (2013), Manajemen Sumbert DayaManusia Untuk Perusahaan, Rajawali Pers, Jakarta.

Robbin, S. P. \& Timothy A. Judge. (2008), Perilaku Organisasi, alih bahasa oleh Hadyana Pujaatmaka, Salemba Empat, Jakarta.Sedarmayanti, (2012), Manajemen Sumber Daya Manusia, Refika Aditama, Bandung

Siagian, Sondang P. (2011). Manajemen Sumber Daya Manusia. Cetakan Ke-19, Bumi Aksara, Jakarta.

Sugiyono, 2015, Metode Penelitian Kuantitatif, Kualitatif, dan R\&D, Cetakan Ke-22, Alfabeta, Bandung. 
Sutrisno, E. (2014), Manajemen Sumber Daya Manusia, Prenada Media, Yogyakarta.

Yuniarsih, Tjuju dan Suwanto, (2009), Manajemen Sumber Daya Manusia, Alvabeta, Bandung.

Yusani, Pebri (2016), Pengaruh Penempatan Kerja Terhadap Semangat Kerja Karyawan PT Perkebunan Nusantara VII, Palembang. 